\title{
Pendampingan Pencatatan Transaksi Keuangan pada Keluarga Nelayan di Desa Banyusangkah Kecamatan Tanjung Bumi
}

\author{
Aulia Dawam 1) \\ 1) STKIP PGRI BANGKALAN \\ dawam@stkippgri-bkl.ac.id
}

\begin{abstract}
ABSTRAK: Pengetahuan tentang pengelolaan keuangan dan anggaran tidak hanya kegiatan yang hanya dilakukan di perusahaan-perusahaan industri, perdagangan atau semacamnya, namun sudah menjadikan keharusan bagi seluruh rumah tangga untuk dapat melakukannya, karena perlu disadari bahwa rumah tangga yang didalamnya terdapat suami, istri dan anak-anak merupakan unit perusahaan yang kecil. Tujuan dari pendampingan ini adalah untuk mengetahui pemahaman manajemen rumah tangga keluarga nelayan, untuk mendampingi pencatatan transaksi keuangan yang baik, untuk mengetahui hambatan dalam penerapan manajemen keluarga dan melihat apakah ada pengaruh internalisasi terhadap pengeloaan keuangan keluarga nelayan di Desa Banyusangkah Kecamatan Tanjung Bumi, yang pendapatannya bergantung pada hasil tangkap yang di pengaruhi oleh kondisi alam terutama angin, gelombang, dan arus laut.
\end{abstract}

Kata kunci : Transaksi Keuangan, Keluarga Nelayan, Rumah Tangga

ABSTRACT: Knowledge about financial and budget management is not only an activity that is only carried out in industrial, commercial or similar companies, but it has made it imperative for all households to be able to do it, because it needs to be realized that the household in which there are husband, wife and children is a small company unit. The purpose of this assistance is to find out the understanding of fisherman family household management, to accompany the recording of good financial transactions, to find out the obstacles in the implementation of family management and see whether there is an influence of internalization on the financial management of fishermen families in Banyusangkah Village, Tanjung Bumi District, whose income depends on the catch that is influenced by natural conditions, especially wind, waves and ocean currents. Keywords: financial transactions, fishing families, households

\section{PENDAHULUAN}

Nelayan adalah sekelompok masyarakat yang mempunyai mata pencaharian dari menangkap ikan. Kebanyakan masyarakat yang tinggal di pesisir pantai mayoritasnya hanya memiliki mata pencaharian sebagai nelayan atau menagkap ikan. Sumberdaya kehidupan masyarakat nelayan di cirikan dari pendidikan dan keterampilan masyarakat, masyarakat nelayan mayoritasnya memiliki pengetahuan yang rendah akan ilmu pendidikan, mereka hanya memiliki kemampuan untuk mencari uang dengan mengandalkan fisik tidak dengan ilmu pendidikan.

Pengetahuan tentang pengelolaan keuangan sangatlah penting bahkan sekarang tidak hanya di butuhkan perusahaan, industry, perdagangan dan sebagainya. Tapi keharusan bagi keluarga melakukan pengelolaan keuagan, karena perlu di sadari di rumah tangga terdapat suami istri, dan anak yang merupakan unit perusahaan yang kecil yang sangat perlu melakukan pengelolaan keuangan agar dapat mengelola keuangan rumah 
tangganya. Bagi seorang yang telah menikah dan berkeluarga maka kebutuhannya terhadap uang akan semakin bertambah, karena semula uang yang dimilikinya hanya digunakan untuk kepentingan diri sendiri, dengan adanya keluarga maka ia juga harus menanggung kebutuhan-kebutuhan keluarganya, baik kebutuhan konsumsi rumah tangga, suami/istri atau kebutuhan anak bila keluarga tersebut telah mempunyai anak.

Untuk dapat mencapai tujuan hidup seseorang harus mengatur pendapatan yang akan dikeluarkannya, pengeluaran-pengeluaran tersebut harus diatur agar nantinya tujuan yang diinginkan tercapai. Kebutuhan dalam keluarga tidak hanya berupa kebutuhankebutuhan jangka pendek yang bersifat mendesak atau pengeluaran rutin seperti belanja bulanan, dana sekolah anak dan biaya-biaya rutin lainya, melainkan bila ditinjau secara lebih jauh terdapat kebutuhan lain di dalam keluarga yang sering kurang dipikirkan, yaitu kebutuhan jangka panjang yang harus dipenuhi dikemudian hari atau masa yang akan datang. Mengurus dapur rumah tangga memang tidak semudah membalikkan telapak tangan. Apalagi bila pemasukan keluarga tidak menentu. Kestabilan ekonomi di dalam keluarga merupakan salah satu faktor yang cukup menentu kebahagiaan di dalam keluarga, karena penghasilan yang tidak cukup, tetapi karena keluarga tersebut kurang bijaksana di dalam membelanjakan uang atau pendapatan. Latar belakang keluarga, nilainilai yang dianut dalam keluarga dan kebudayaan yang dimiliki mempengaruhi cara berfikir seseorang mengenai uang dan mengelola uang.

Pada saat musim paceklik tidak jarang para keluarga nelayan tidak memperoleh hasil tangkap sama sekali sehingga terjadi penurunan pendapatan, dengan tidak adanya uang para nelayan berbondong-bondong mencari warung-warung terdekat untuk melakukan hutang, agar bisa menghidupi rumah tangga mereka. Tidak jarang juga ibuibu rumah tangga di Desa Banyusangkah ikut bekerja guna untuk membantu para suami untuk mencari nafkah. Ada yang bekerja sebagai menjemur ikan, berjualan dan ada juga yang sebagai tukang cuci pakaian. Dengan cara itu ibu-ibu keluarga nelayan di Desa Banyusangkah merasa bisa membantu suaminya untuk menghidupi keluarga mereka, dan tidak jarang juga anak-anak mereka putus sekolah hanya karena kurangnya perekonomian rumah tangga, dan akhirnya seorang anak juga ikut mencari uang dengan cara mengikuti jejak ayahnya sebagai nelayan.

Pendapatan masyarakat nelayan di Desa Banyusangkah pada dasarnya bergantung terhadap pemanfaatan sumber daya perikanan yang terdapat dilaut. Pendapatan masyarakat nelayan secara tidak langsung akan mempengaruhi kualitas hidup mereka, karena pendapatan dari hasil berlayar merupakan sumber pemasukan utama atau bahkan satu-satunya bagi mereka, sehingga besar kecilnya pendapatan akan sangat memberikan pengaruh terhadap kehidupan mereka. Oleh karena itu, dalam pendampingan kali ini peneliti ingin membantu memberikan pelatihan pembuatan pencatatan transaksi keuangan yang baik dan benar bagi ibu-ibu keluarga nelayan di Desa Banyusangkah Kecamatan Tanjung Bumi. 


\section{PERMASALAHAN}

Berdasarkan pada uraian analisis situasi diatas dapat ditemukan bahwa permasalahan para ibu-ibu perkumpulan keluarga nelayan di Desa Banyusangkah Kecamatan Tanjung Bumi mempunyai kelemahan dalam memanajemen pencatatan dalam transaksi keuangannya, hal ini yang diakibatkan oleh kurangnya pemahaman pendidikan tentang akuntansi, pendapatan para kepala keluarga yang tidak menentu sebagai nelayan, dan kebiasaan buruk mengutang.

\section{METODE PELAKSANAAN}

Metode pendampingan ini pelaksana melakukan beberapa tahap. Tahapan 1 pengumpulan data penelitian dengan cara observasi dan wawancara terhadap keluarga nelayan. Tahap ke 2 peneliti akan melakukan pendampingan dan sosialisasi dalam satu waktu dan satu tempat untuk pencatatan transaksi keuangan serta memberikan pemahaman terkait manajemen rumah tangga yang baik. Tahap ke 3 peneliti akan melakukan evaluasi dari hasil kegiatan. Tahap 4 melakukan monitoring dari hasil pendampingan agar nantinya mereka para keluarga nelayan khususnya ibu-ibu dapat lebih mandiri dalam melakukan pencatatan transaksi keuangannya sehari-hari.

\section{HASIL DAN PEMBAHASAN \\ Gambaran Umum Lokasi Penelitian}

Desa Banyusangkah merupakan bagian dari wilayah Kecamatan Tanjung Bumi Kabupaten Bangkalan yang berada di bagian pesisir utara dari Pulau Madura tepatnya berada pada 6.883342 LS - 113.024244 BT. Desa ini salah satu pemasok ikan terbesar di wilayah Kabupaten Bangkalan. Perbatasan dengan beberapa desa diantaranya Desa Tlango di timur, Desa Paseseh di selatan, Kecamatan Sepuluh di barat, dan di utara Selat Madura. Luas desa 175.70 Ha Panjang garis pantai 1.44 km Ketinggian dari permukaan laut 2 mdpl. Jumlah total penduduk dengan rincian Jumlah KK 1.740 jiwa dimana Lakilaki 1.647 jiwa dan Perempuan 1.774 jiwa.

Desa Banyusangkah merupakan desa pesisir, sehingga rata-rata masyarakatnya memiliki mata pencaharian sebagai nelayan tradisional dengan alat tangkap sederhana, diantaranya jaring, disamping itu ada juga yang meminjam dari tengkulak. Namun persoalan besar yang di rasakan oleh masyarakat adalah beroperasinya lamparan dasar yang cara kerjanya sama dengan pukat harimau. Lamparan ini juga menjarah daerah penangkapan nelayan tradisional sehingga menurunkan pendapatan nelayan. Memang rata-rata masyarakat nelayan Banyusangkah hanya sebagai pekerja di kapal, sedangkan yang memiliki kapal adalah orang-orang konglomerat yang tidak ikut melaut serta TPI. Sebagai masyarakat yang tinggal di dekat pesisir, maka tidak hanya orang tua atau yang sudah berkeluarga saja yang ikut melaut atau pun bekerja membantu menjualkan ikan. Namun yang masih muda-muda ataupun berkeluarga juga ikut kelaut. Maka peneliti 
hanya meneliti para nelayan yang hanya dipekerjakan dengan gaji yang tak seberapa untuk menghidupi istri dan anak-anaknya, artinya peneliti hanya meneliti nelayan yang sudah berumah tangga.

\section{Pemahaman Pengelolaan Keuangan Rumah Tangga Keluarga Nelayan}

Sebelum peneliti melakukan pendampingan pengelolaan keuangan keluarga, peneliti menjelaskan beberapa hal penting bahwa seseorang harus mampu memahami pengelolaan keuangan itu sendiri. Pemahaman pengelolaan keuangan sangatlah penting bagi seseorang, karena dengan kemampuan tersebut seseorang dapat memahami pengelolaan keuangan dengan baik, maka nantinya juga akan mampu mengatur keuangannya dengan baik. Tidak memandang besar atau kecilnya pendapatan, tinggi atau tidaknya tingkat pendidikan, sebuah keluarga harus memahami pengelolaan keuangan keluarga. Begitu juga halnya keluarga nelayan, meski pun letak daerah yang jauh dari kota, tingkat pendidikan yang rendah serta tidak menentunya pendapatan yang diterima mereka harus mampu memahami pengelolaan keuangan yang baik.

Perencanaan keuangan jangka panjang merupakan rencana di masa depan. Hal ini sangatlah penting bagi sebuah keluarga, karena suatu keluarga tidak mungkin tidak memiliki keinginan, seperti menguliahkan anaknya, ataupun merenovasi rumah, membeli rumah, membeli kendaraan dan lain sebagainya. Hal ini tentu saja membutuhkan suatu rencana, hingga keinginan itu akan dapat dicapai. Oleh karena itu, dengan adanya rencana di masa depan tersebut sebuah keluarga harus mengatur keuangannya dengan menabung untuk masa depannya. Dengan pendapatan masyarakat nelayan yang berkisar Rp.50.000,sampai Rp.100.000,- per harinya dan juga dikarenakan bergantung pada keadaan cuaca, ataupun musim ikan serta tingginya biaya hidup. Maka keluarga nelayan kecamatan barus mengatakan bahwa tidak melakukan perencanaan keuangan dalam hal jangka panjang dan jangka pendek. Dari wawancara yang peneliti lakukan hanya satu keluarga yang melakukan perencanaan keuangan keluarga.

Penerapan Anggaran Rumah Tangga Upaya mengatur dan mengelola keuangan keluarga secara baik dan bijak, efektif dan efisien bisa diimplementasikan dengan menyusun anggaran pendapatan dan belanja keluarga (APBK). Secara sederhana APBK adalah suatu proses perencanaan dan pengelolaan dan pengendalian aliran kas masuk (pendapatan) dan aliran kas keluar (pengeluaran) suatu keluarga untuk periode tertentu dimasa mendatang, misalnya mingguan, bulanan atau tahunan. Dalam pegertian yang lebih luas, APBK merupakan suatu rencana yang disusun secara sistematis dalam bentuk angka dan dinyatakan dalam unit moneter yang meliputi seluruh kegiatan keluarga untuk jangka waktu (periode) tertentu di masa yang akan datang. Ketika menyusun anggaran belanja, susunlah daftar belanja atau barang yang dibutuhkan, baik harian ataupun setiap bulannya. Perlu diperhatikan berapa anggaran yang kita bajatkan dan daftar barang akan kita beli. Sehingga tidak mengalami lebih besar pasak dari pada tiang. Membuat daftar belanja bukan hanya menggambarkan besarnya pengeluaran yang akan kita gunakan. 
Melainkan juga mengontrol agar tidak berbelanja secara berlebihan. Sehingga yang dibeli sesuai dengan kebutuhan bukan keinginan.

\section{Hasil Pelaksanaan Kegiatan}

Kegiatan Pendampingan pencatatan transaksi keuangan pada keluarga nelayan di desa Banyusangkah Kecamatan Tanjung Bumi Kabupaten Bangkalan untuk meningkatkan sistem laporan keuangan dilaksanakan dalam beberapa tahap dalam satu hari. Adapun susunan acara pendampingan sebagai berikut:

Tabel 1. Pelaksanaan Kegiatan

\begin{tabular}{|c|c|c|c|}
\hline No. & Hari, Tanggal & Materi & Waktu \\
\hline \multirow{5}{*}{1.} & \multirow{5}{*}{$\begin{array}{l}\text { Minggu, } 13 \\
\text { Oktober } 2019\end{array}$} & Registrasi Peserta & $07.30-08.00$ \\
\hline & & Pengantar/Pendahuluan Akuntansi & $12.00-13.00$ \\
\hline & & $\begin{array}{l}\text { Langkah-langkah pembuatan Anggaran } \\
\text { Pendapatan Dan Belanja Keluarga } \\
\text { (APBK) }\end{array}$ & \multirow{3}{*}{$13.00-16.00$} \\
\hline & & Tanya Jawab & \\
\hline & & 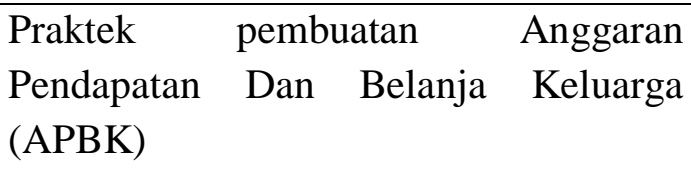 & \\
\hline
\end{tabular}

Sumber: Diolah Peneliti

Pelaksanaan Pendampingan pencatatan transaksi keuangan pada keluarga nelayan di desa Banyusangkah Kecamatan Tanjung Bumi Kabupaten Bangkalan ini berjalan selama satu hari yaitu pada hari Minggu 13 Oktober 2018. Acara Pertama diawali dengan registrasi peserta setelah itu dilanjutkan dengan pemberian materi pengantar pemahaman tentang akuntansi kemudian penjelasan mengenai langkah-langkah pembuatan Anggaran Pendapatan Dan Belanja Keluarga (APBK), setelah itu tanya jawab dan praktek langsung dalam pembuatan Anggaran Pendapatan Dan Belanja Keluarga (APBK) yang berakhir pada pukul 16.00 WIB.

\section{Pembahasan}

Pelaksanaan Pendampingan pencatatan transaksi keuangan pada keluarga nelayan di desa Banyusangkah Kecamatan Tanjung Bumi Kabupaten Bangkalan pada hari Minggu, 13 Okotober 2019 berjalan dengan lancar. Materi pertama yang diberikan adalah pengenalan atau pendahuluan mengenai akuntansi. Pemateri memberikan penjelasan pentingnya pencatatan transaksi keuangan bagi rumah tangga. Sebagian peserta pendampingan belum mengerti fungsi dan pembuatan pencatatan transaksi keuangan yang baik, bahkan sebagian besar peserta pendampingan menganggap 
bahwa pencatatan transaksi keuangan keluarga adalah bidang yang rumit, susah, merepotkan dan menghabiskan waktu.

Materi dalam pendampingan ini hanya bermaksud untuk mengetahui penerapan pencatatan transaksi keuangan rumah tangga keluarga nelayan dengan melihat pos penerimaan dan pos pengeluaran keuangannya.

\section{a. Pos Pendapatan Dan Pos Pengeluaran Pendapatan}

Merupakan hasil dari kerja keras sesorang baik bersifat tetap maupun tidak, baik dengan jumlah yang sama maupun tidak jika dimanfaatkan dan diatur sebaik mungkin untuk kebutuhan sehari-hari maka tidak akan pernah merasa kekurangan. Agar pengeluaran tidak amburadul maka sebuah keluarga bisa membuat beberapa pos pengeluaran sebagai berikut:

1. Pengeluaran yang rutin dan penting. Yaitu pengeluaran yang mau tidak mau atau suka tidak suka harus kita keluarkan setiap bulan. Seperti tagihan listrik, telepon, air, tagihan keamanan dan tagihan kartu kredit bagi yang memiliki. Kebutuhan sekolah anak, belanja sehari-hari untuk keperluan makan, belanja bulanan untuk kebutuhan pakaian dan kebutuhan rumah seperti sabun, detergen dan lain-lain, biaya sehari-hari untuk keperluan transportasi dan sebagainya.

2. Penting dan tidak rutin. Yaitu biaya yang harus kita keluarkan namun tidak rutin waktunya. Seperti untuk refreshing, servis kendaraan, keperluan hari raya dan lain-lain. Tidak penting dan tidak rutin. Yaitu pengeluaran yang dikeluarkan berdasarkan keinginan bukan kebutuhan. Seperti membeli kendaraan, gadget dan lai-lain.

3. Kepentingan jangka panjang. Yaitu kebutuhan masa depan. Seperti biaya melanjutkan sekolah anak hingga lulus, membei rumah, renovasi rumah ataupun mengganti kedaraan baru.

b. Pengeluaran Yang Lebih Besar Dari Pemasukan

Dari beberapa pemaparan diatas menunjukkan sebenarnya bahwa rumah tangga mereka memang harus benar-benar mengatur dan mengelola keuangan sebaik-baiknya untuk berjaga-jaga dalam hal-hal pengeluaran yang tak terduga. Karena keadaan cuaca memang tidak mudah kita tebak, belum lagi jika ada peraturan dari dinas kelautan tidak boleh melaut dalam beberapa hari bahkan sampai berminggu. Maka untuk menutupi semua itu harus ada, keuangan yang memang disediakan jauh-jauh hari. Sehingga ketika pengeluaran lebih besar dari pendapatan, maka dapat tertutupi oleh persediaan yang dimiliki. Untuk memenuhi kebutuhan, rumah tangga keluarga harus memiliki pendapatan, tanpa pendapatan, keluarga tidak mempunyai dana yang cukup untuk memperoleh barang ataupun jasa, sumber pendapatan bisa bersifat tetap dan tidak tetap. Untuk memenuhi kebutuhan, rumah tangga keluarga harus mengeluarkan dana sebagai 
pengorbanan untuk memperoleh barang atau jasa. Besar kecil pengeluaran tergantung pada macam, banyak, dan tingkat harga barang atau jasa yang dibutuhkan.

c. Dana Cadangan dan Dana Tabungan

Menabung berarti menyimpan daya beli saat ini untuk digunakan pada masa yang akan datang. Sehingga menabung bisa diartikan, persiapan dana untuk masa depan. Karena kita tidak akan pernah tahu bagaimana kehidupan kita selanjutnya. Jika kita ingin mengatur uang, salah satu yang bisa kita lakukan adalah memisahkan tabungan dengan biaya hidup, ataupun dengan tabungan sementara, alias tabungan yang hanya disimpan untuk sesaat. Jika kita menabung, maka usahakan tabungan kita terdiri dari dua macam, yang satu untuk tabungan sesaat yaitu untuk kebutuhan sehari-hari jika mengalami kekurangan dan satu lagi tabungan masa depan, yaitu untuk pendidikan anak nantinya, jaminan masa tua dan lainnya serta tabungan ini tidak bisa diambil setiap waktunya. Hal ini dapat mencegah kita untuk menggunakan dana yang sudah ditabung dan mencampuradukkan dana tabungan dan dana biaya hidup. Yang pada kenyataannya banyak orang yang sudah menabung, kemudian menarik kembali dana yang disisihkan itu untuk belanja sehari-hari. Bahkan terkadang, jumlah yang dibelanjakan jauh lebih besar dari yang ditabung. Sebenarnya, meskipun kita membuat beberapa tabungan, kita masih tetap bisa mengambilnya karena kitalah yang memegang kendalinya. Oleh karena itu kelancaran dalam proses mengatur keuangan ini tergantung pada diri kita sendiri. Sehingga kita harus bisa mendisiplinkan diri kita sendiri. Memang kenyataan yang terjadi orang mencampuradukkan dana tabungan dengan biaya hidup cenderung kesusahan dengan setengah mati untuk menabung dikarenakan biaya hidup yang tidak akan ada habisnya.

\section{Faktor Pendukung Kegiatan}

Secara umum acara pendampingan pencatatan transaksi keuangan pada keluarga nelayan di desa Banyusangkah Kecamatan Tanjung Bumi Kabupaten Bangkalan ini berjalan dengan lancar. Hal ini dicapai berkat dukungan masyarakat Desa Banyusangkah Kecamatan Tanjung Bumi dengan menyediakan fasilitas, tempat serta sarana dan prasarana. Masyarakat Desa Banyusangkah menyambut baik acara pendampingan pencatatan transaksi keuangan pada keluarga nelayan ini sehingga kegiatan pendampingan ini kedepannya tetap berlanjut di masa yang akan datang untuk kemajuan masyarakat di desa Banyusangkah Kecamatan Tanjung Bumi Kabupaten Bangkalan terutama desa pesisir lainnya yang memiliki permasalahan keluarga nelayan yang sama. Dengan harapan warga nantinya disana dapat secara mandiri dan lebih baik lagi dalam melakukan pencatatan, penganggaran, dan pembelanjaan bagi keluarga nelayan yang sedikit banyak bergantung pada kondisi alam (melaut). 


\section{Faktor Penghambat Kegiatan}

Beberapa hambatan yang dialami pada saat pendampingan antara lain: kesalahan teknis, seperti kurang kerasnya perangkat pengeras suara (sound system) sehingga menyebabkan suara tidak terdengar sampai pada peserta yang dibelakang dan faktor tingkat pendidikan para keluarga nelayan yang masih rendah serta beberapa peserta ada yang tuna aksara.

\section{Luaran Yang Dicapai}

Setelah dilaksanakannnya pendampingan pencatatan transaksi keuangan pada keluarga nelayan di desa Banyusangkah yang berlangsung dalam satu hari diharapkan peserta mampu membuat secara mandiri pencatatan, penganggaran, dan pembelanjaan yang baik dan bijak bagi keluarganya.

\section{KESIMPULAN DAN SARAN}

\section{Kesimpulan}

Kegiatan pendampingan pencatatan transaksi keuangan pada keluarga nelayan di desa Banyusangka Kecamatan Tanjung Bumi Kabupaten Bangkalan untuk meningktakan pemahaman dalam pencatatan, penganggaran dan pembelanjaan rumah tangga nelayan yang lebih baik dan lebih bijak, sebenarnya rumah tangga nelayan memang harus benar-benar mengatur dan mengelola keuangan sebaik-baiknya untuk berjaga-jaga dalam hal-hal pengeluaran yang tak terduga. Karena keadaan cuaca memang tidak mudah kita tebak, belum lagi jika ada peraturan dari dinas kelautan tidak boleh melaut dalam beberapa hari bahkan sampai berminggu. Maka untuk menutupi semua itu harus ada, keuangan yang memang disediakan jauh-jauh hari. Sehingga ketika pengeluaran lebih besar dari pendapatan, maka dapat tertutupi oleh persediaan yang dimiliki. Pada saat pendampingan semua peserta antusias mengikuti acara hingga selesai dan merasakan manfaat pendampingan bagi kemajuan usaha mereka.

\section{Saran}

Pelatihan serupa dapat dilaksanakan kembali dengan peserta (audience) yang lebih banyak/luas seperti pendampingan bagi keluarga nelayan disekitar Kabupaten Bangkalan yang langsung diawasi oleh dinas kelautan dan perikanan. Di samping itu fasilitas untuk presentasi seperti LCD, pengeras suara sebaiknya di periksa kembali sebelum acara dilaksanakan.

\section{DAFTAR PUSTAKA}

Jatmiko, Widhi. "Implementasi Manajemen Keuangan Rumah Tangga keluarga Pendiunan TNI-AL Di Kompleks TNI-Al Tebel Gedangan Sidoarjo". Skripsi, Fakultas Ekonomi UPN Veteran Surabaya, 2010

Senduk, Safir. Mengelola Keuangan Keluarga, (Jakarta: PT Elex Media Komputindo, 2000 
Pendampingan Pencatatan Transaksi ... (Dawam)

Sugianto, dkk. Sistem Bagi Hasil Pada Komunitas Nelayan, Medan: IAIN PRESS, 2014 Sugiyono. 2012. Metode Penelitian Kuantitatif, Kualitatif, dan RD. Bandung: Alfabeta. Surono. Anggaran Pendapatan dan Belanja Keluarga, Yogyakarta : Graha Ilmu, 2008 
Volume 3, Nomor 2, September 2019 